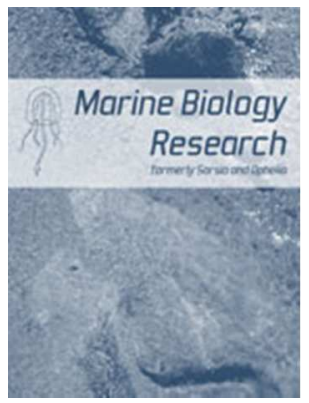

\title{
Impact of harvesting cleaner fish for salmonid aquaculture assessed from replicated coastal marine protected areas
}

\begin{tabular}{|c|c|}
\hline Journal: & Marine Biology Research \\
\hline Manuscript ID & MBR-2016-0266 \\
\hline Manuscript Type: & Original Article \\
\hline Date Submitted by the Author: & 13-Aug-2016 \\
\hline Complete List of Authors: & $\begin{array}{l}\text { Halvorsen, Kim; University of Agder, Department of Natural Sciences; } \\
\text { Institute of Marine Research, Austevoll Research Station, } 5392 \text { Storebø; } \\
\text { University of Oslo, Department of Biosciences, Centre for Ecological and } \\
\text { Evolutionary Syntheses (CEES), } \\
\text { Larsen, Torkel; Institute of Marine Research Flødevigen, Nye Flødevigveien } \\
\text { 20, } 4817 \text { His, Norway. } \\
\text { Sørdalen, Tonje; University of Agder, Department of Natural Sciences; } \\
\text { University of Oslo, Department of Biosciences, Centre for Ecological and } \\
\text { Evolutionary Syntheses (CEES), } \\
\text { Vøllestad, Leif Asbjørn; University of Oslo, Department of Biosciences, } \\
\text { Centre for Ecological and Evolutionary Syntheses (CEES), } \\
\text { Knutsen, Halvor; Institute of Marine Research, } \\
\text { Olsen, Esben; University of Agder, Department of Natural Sciences; } \\
\text { Institute of Marine Research Flødevigen, Nye Flødevigveien 20, } 4817 \text { His, } \\
\text { Norway. ; University of Oslo, Department of Biosciences, Centre for } \\
\text { Ecological and Evolutionary Syntheses (CEES), }\end{array}$ \\
\hline Keywords: & $\begin{array}{l}\text { Marine protected areas, aquaculture-environment interactions, wrasse, } \\
\text { fisheries management }\end{array}$ \\
\hline
\end{tabular}


1 Impact of harvesting cleaner fish for salmonid aquaculture assessed from replicated 2 coastal marine protected areas

3 Kim Tallaksen Halvorsen (kim.a.halvorsen@uia.no), tel: +47 40016601 cor. author

4 First affiliation: Centre for Coastal Research, Department of Natural Sciences, University of Agder, PO Box 422 , 4604 Kristiansand, 5 Norway.

6 Second: Institute of Marine Research, Austevoll Research Station, 5392 Storebø, Norway

7 Third: Department of Biosciences, Centre for Ecological and Evolutionary Syntheses (CEES), University of Oslo, PO Box 1066 Blindern, 80316 Oslo, Norway.

9 Torkel Larsen (Torkel.larsen@gmail.com)

Affiliation: Institute of Marine Research Flødevigen, Nye Flødevigveien 20, 4817 His, Norway.

Tonje Knutsen Sørdalen (tonje.k.sordalen@uia)

First affiliation: Centre for Coastal Research, Department of Natural Sciences, University of Agder, PO Box 422, 4604 Kristiansand, Norway.

0316 Os: Department of

Leif Asbjørn Vøllestad (asbjorn.vollestad@ibv.uio.no)

Affiliation: Department of Biosciences, Centre for Ecological and Evolutionary Syntheses (CEES), University of Oslo, PO Box 1066 Blindern, 0316 Oslo, Norway. 0316 Oslo, Norway.

Esben Moland Olsen (esben.m.olsen@uia.no)

First affiliation: Centre for Coastal Research, Department of Natural Sciences, University of Agder, PO Box 422, 4604 Kristiansand, Norway.

Second: Institute of Marine Research Flødevigen, Nye Flødevigveien 20, 4817 His, Norway.

Third: Department of Biosciences, Centre for Ecological and Evolutionary Syntheses (CEES), University of Oslo, PO Box 1066 Blindern, 0316 Oslo, Norway.

30 The research was conducted at: the Institute of Marine Research Flødevigen, Nye 31 Flødevigveien 20, 4817 His, Norway.

\section{Acknowledgements}

We would like to thank Benjamin Hanssen for assistance during fieldwork and otolith preparation and analyses.

\section{Funding}

This work was supported by the Norwegian research council under grant (project PROMAR - 201917); the University of Agder through funding from the Norwegian Ministry of Education and Research and the Öresund-Kattegat-Skagerrak Interreg program (project: MarGen)

\section{Running head}

41 Impact of harvesting cleaner wrasse for salmonid aquaculture 


\section{Abstract}

In Norway, wrasse (Labridae) fisheries have increased markedly since 2010. Wrasses are used as cleaner fish in salmonid aquaculture to control sea-lice infestations. However, fundamental knowledge on demography and abundance of the targeted wrasse populations in Norwegian waters is lacking, and the consequences of harvesting at the current intensity have not been assessed. Here, we compared abundance, size, age and sex-ratio of goldsinny wrasse (Ctenolabrus rupestris) and corkwing wrasse (Symphodus melops) between marine protected areas (MPAs) and control areas open for fishing in four localities on the Skagerrak coast in Southern Norway. The catch per unit effort (CPUE) of goldsinny larger than the minimum size limit was 33-65 \% higher within MPAs, while for corkwing three out of four MPAs had higher CPUE with the relative difference between MPAs and control areas ranging from -16 $\%$ to $92 \%$. Moreover, corkwing, but not goldsinny, was significantly older and larger within MPAs than in control areas. Sex ratios did not differ between MPAs and control areas for neither species. Our study suggest that despite its short history, the wrasse fisheries have significant impacts on the target populations and further, that small MPAs hold promise as a management tool for maintaining natural population sizes and size structure. Goldsinny, being a smaller sized species also seems to benefit from the traditional minimum size limit management tool, which applies outside MPAs.

\section{Key words}

Marine protected areas, aquaculture-environment interactions, wrasse, fisheries management

\section{Introduction}

Different species of wrasse (Labridae) are among the most numerous fish species on shallow rocky reefs and coastlines in Northern Europe, but their commercial value as food fish is low due to their relatively small body size. However since the late 1980's, wild caught goldsinny wrasse (Ctenolabrus rupestris (Linnaeus, 1758)), corkwing wrasse (Symphodus melops (Linnaeus, 1758)), ballan wrasse (Labrus bergylta Ascanius, 1767) and rock cook (Centrolabrus exoletus (Linnaeus, 1758)), has been used as cleaner fish in open-pen farming of Atlantic Salmon (Salmo salar Linnaeus, 1758), to reduce infestations of salmon lice (Lepeophtheirus salmonis Krøyer, 1837) in Norway and the British Isles (Bjordal 1988; Darwall et al. 1992; Treasurer 1996). The Norwegian demand of wild caught wrasse increased sharply after 2009 when the lice problem intensified as the lice had evolved resistance to most 
73

of the available pesticides (Costello 2009; Besnier et al. 2014; Halvorsen et al. 2016). In 2014 and 2015, wrasse landings surpassed 20 million individuals, with corkwing and goldsinny wrasse as the dominating species (The Norwegian Directorate of Fisheries). Wrasses are caught by small boats operating inshore using fyke nets and pots set at depths less than ten meters and transported with boats or trucks to the salmon farms. The fishery is regulated with minimum size limits, gear modifications for escapement of undersized fish and a fishing closure from January until July. From 2015, minimum size limits are species-specific (goldsinny $11 \mathrm{~cm}$, corkwing $12 \mathrm{~cm}$ and ballan $14 \mathrm{~cm}$ ), after previously being the same for all wrasse $(11 \mathrm{~cm})$ (Skiftesvik et al. 2014a). In addition, a total landing cap of 18 million individuals has been set in 2016, divided among three regions (South: 4 million, West: 10 million and North: 4 million individuals).

Whether and how the wrasse fishery affects the natural populations in Norway has not been investigated and the increasing exploitation has attracted concerns from the scientific community (Espeland et al. 2010; Skiftesvik et al. 2014b,a; Halvorsen et al. 2016). The sedentary behaviour of wrasses poses a challenge for management and fisheries assessments; they hold territories and have small home ranges (Hilldén 1981; Potts 1985; Sayer 1999; Villegas-Ríos et al. 2013). Also, large differences in species composition, population densities and life history traits have been observed at small spatial scales (Sayer et al. 1996a; Varian et al. 1996; Skiftesvik et al. 2014b). During the initial wave of wrasse fisheries on the British Isles in the 1990's, harvested populations of corkwing and goldsinny showed signs of reductions in abundance and changes in size structure (Darwall et al. 1992; Sayer et al. 1996b; Varian et al. 1996). Probably, around 150000 wrasses were caught and used in Scotland in 1994 (Treasurer 1996), while the total catch in Norway in 2015 reached 21 million individuals. The higher intensity of the current Norwegian fishery raises concerns about its long-term sustainability. However, fishery impacts on the wild wrasse populations in Norway remain unclear, partly due to data deficiency.

Marine protected areas (MPAs) represent a tool for management and conservation where selected areas are partially or completely closed for harvesting. Depending on the MPA design (size, position, distance to nearby MPAs and fishing pressure) and the behavior and ecology of the protected species, this may preserve natural densities and demography and in some cases increase fisheries yield through spillover of adults or increased overall recruitment (Gaines et al. 2010; Goñi et al. 2010; Babcock et al. 2010). MPA's has specifically been highlighted as useful for managing protecting sedentary reef fishes (Roberts and Polunin 
1991; Carr \& Reed 1993; Gunderson et al. 2008). On the Skagerrak coastline in Southern Norway, six smaller partial protected areas were established in 2006 (four) and 2012 (two), and have been demonstrated to yield positive effect on biomass, size structure and mortality rates of European lobster (Homarus gammarus (Linnaeus, 1758)) and Atlantic cod (Gadus morhua Linnaeus, 1758) (Moland et al. 2013; Fernández-Chacón et al. 2015). These are partially protected areas where passive standing gears are prohibited (gillnets, pots and fyke nets). Wrasses are effectively fully protected in all these MPA's since they are normally not targeted in recreational hook-and-line fisheries.

Here, we studied abundance and age, size and sex composition of goldsinny and corkwing wrasse on the Skagerrak coastline, where harvested wrasse is exported to the salmon farming region in Western and Northern Norway. Coastal MPAs in Skagerrak provide the opportunity to assess whether the increase in exploitation have affected important population parameters. Wrasse were sampled with passive gears in four of the MPAs and compared with corresponding control areas of similar habitat, open to commercial fisheries. We predicted MPAs to have relatively higher catch per unit effort and the wrasse to be older and larger. As males have been found to be the larger sex in both species (Dipper \& Pullin 1979; Sayer et al. 1996a; Halvorsen et al. 2016), we also predicted the sex ratio to be more female-skewed in fished areas. A secondary objective was to compare the bycatch, size, age and sex composition of wrasse caught in fyke nets and baited pots, which are the two types of gear used in the commercial wrasse fishery and therefore potentially valuable for evaluating gear based management regulations.

\section{Material and Methods}

\section{Study area}

The four MPA's and control areas are situated on the Norwegian Skagerrak coast outside the town of Arendal (58 $24^{\prime}-25^{\prime} \mathrm{N}, 8^{\circ} 43^{\prime}-46^{\prime} \mathrm{E}$, MPA established 2006), Tvedestrand (two MPAs: inner area at $58^{\circ} 34^{\prime}-36^{\prime} \mathrm{N}, 8^{\circ} 56^{\prime}-9^{\circ} 0^{\prime} \mathrm{E}$ and outer area at $58^{\circ} 35^{\prime}-37^{\prime} \mathrm{N}, 9^{\circ} 4^{\prime}-7^{\prime} \mathrm{E}$, MPAs established 2012) and Risør (58 42'-44'N, 9 ${ }^{\circ}$ 13'-15'E MPA established 2006) (Figure 2). The MPAs are of similar size $\left(0.62-5.27 \mathrm{~km}^{2}\right)\left(4.1 \mathrm{~km}^{2}-\right.$ Tvedestrand Inner, $5.27 \mathrm{~km}^{2}-$ Tvedestrand outer, $1.1 \mathrm{~km}^{2}$ - Flødevigen, $0.62 \mathrm{~km}^{2}$ - Risør). The nearby control areas were separated from the MPA's by a depth barrier ( $>20$ meters), or by being more than 900 meter coastline distance from the MPA (Figure 1). Moreover, control areas were selected on the basis of habitat similarity to sites in the corresponding MPA (exposure, kelp coverage and 
138 bottom substrate). Detailed knowledge on previous fishing effort in the control areas was not 139 available, but local wrasse fishermen were consulted and confirmed that the control areas had 140 been fished in the year of study (2013) or in earlier seasons. Wrasse fishers in this region use

141

142

143

144

145

146

147

148

149

150

151

152

153

154

155

156

157

158

159

160

161

162

163

164

165

166

167

168

169 small open boats and fishes at all suitable inshore sites with rocky-kelp covered bottom types (Gjøsaeter 2002). Both pots and fyke nets are in use and several fishers may operate within the same area.

\section{Sampling}

Sampling was conducted from August - September 2013 (Table I). Wrasse were captured with un-baited fyke nets ( 5 meter single leader, $55 \mathrm{~cm}$ diameter entrance ring and leader mesh size of $30 \mathrm{~mm}$ ) and wrasse pots (rectangular prism shaped, $70 \times 40 \times 29 \mathrm{~cm}$, circular entrances (75 $\mathrm{mm}$ diameter), two chambers and $15 \mathrm{~mm}$ mesh-size) baited with 2-3 raw prawns (Pandalus borealis Krøyer, 1838). As in the commercial fishery, the gear was deployed at rocky, kelp covered substrate at one to seven meters depth and hauled the following day. In each site (MPA or control), between 50 or 150 goldsinny and corkwing wrasse were collected for aging and euthanized with an overdose of clove oil. When an adequate sample size for ageing was reached for one of the species, any additional captures were measured for total length. All other fish species were identified, counted and released at site.

\section{Ageing and sex determination}

The total length of the fish was measured to the nearest $\mathrm{mm}$ and sex was determined by examining external coloration and gonad morphology. Corkwing wrasse males are found in two distinct morphs, nesting males and sneaker males (Uglem et al. 2000). Nesting males are readily distinguished from females and sneaker males by having distinct patterns of blue, green and red. The coloration of females and sneaker males is brown-green and they have a distinct blue urogenital papillae. Sneaker males and females are visually indistinguishable in the field, but could readably be sexed by inspecting their gonads. The female gonad is pale or yellow and has clearly visible egg structures, whereas male gonads are opaque, thin and white. For goldsinny, the sexes are similar in appearance, but males have orange or red spots on the lower part of their abdomen behind the pectoral fins (Hilldén 1981). Sagittal otoliths were dissected out, cleaned and stored dry. For aging, the otoliths were placed in black multicelled trays containing $96 \%$ ethanol and photographed under a stereo microscope $(20 \mathrm{x}$; Leica MZ 16 A). The otoliths of both species have broader, opaque (summer) and narrow, translucent (winter) growth increments, which makes them easy to read without further 
170 processing (Sayer et al. 1996a; Uglem et al. 2000). A few goldsinny otoliths $(n=40)$ had a 171 hazy appearance where growth increments could not be reliably identified, and was therefore

172

173

174

175

176

177

178

179

180

181

182

183

184

185

186

187

188

189

190

191

192

193

194

195

196

197

198

199

200

201 not included in statistical analyses. Age was determined by counting winter zones. Two trained people read the otoliths independently and agreed upon the age of the fish, by comparing ages and agreeing about the age of those yielding disparate estimates.

\section{Data analysis}

The total length of sexes was compared with two-sided t-tests assuming unequal variances. We used generalized linear models (GLMs) to test for spatial differences, effects of MPAs and the influence of sampling gear on the following response variables: catch per unit effort (CPUE; the number of wrasse in each fyke net or pot haul), age, total length and sex ratio (the proportion of males). The models were fitted separately for each species with the appropriate distribution of errors. To evaluate whether the responses to protection differed spatially (between localities) and to select models for statistical inferences, we used likelihood ratio tests to compare the goodness of fit of the models with and without an interaction effect between protection and locality:

1) response $=$ Protection + Locality + Gear $+($ Protection $\times$ Locality $)$

2) response $=$ Protection + Locality + Gear

Including the Gear covariate accommodates for any variance arising from the differences in selective properties of the two gear types, as the proportion of the two gear types differed slightly. In addition, assessing gear selectivity has inherent value on its own, given that these are the two gear types used in the commercial fishery. For CPUE, we only included fish larger than or equal to the minimum size limit (11 cm for both species at the time of study -2013$)$, as we did not expect fishing to have affected recruitment yet as the fisheries did not intensify until 2010. CPUE was modeled by a negative binomial error distribution. The length data was modeled with a Gaussian error distribution with normality assumptions checked by diagnostics plots from the fitted model object. For modeling age, the goldsinny data best conformed to a Poisson distribution, checked for over-dispersion by comparing degrees of freedom with residual variance of the model. For corkwing, $65 \%$ of the individuals were either one year old or young-of-the-year. Therefore, corkwing age was transformed to a binary response variable (age $0-1=0$, age $2-4=1$ ) before modeling. A binary response was also used to model sex ratio (the proportion of males). For corkwing, sneaker males were omitted from this analysis. Lastly, we compared the proportion of by-catch species in the two 
202 gear types with a proportion test. When reporting the observed relative difference in means 203 between MPA and control areas, data from both gear types were pooled. All statistical 204 analyses were performed using the R software version 3.2.2; (R Core Team 2015).

\section{Results}

206

207

208

209

210

211

212

213

214

215

216

217

218

219

220

221

222

223

224

225

226

227

228

229

230

231

232

233

In total, 3906 goldsinny and 709 corkwing were captured and measured for total length in the eight study sites from 24 August - 12 September 2013, of these 846 goldsinny and 705 corkwing were aged (Table I). Mean length of goldsinny was $105 \mathrm{~mm}$ (range 56-164), while the mean length of corkwing was $140 \mathrm{~mm}$ (range 60-219). Thus, only $36.6 \%$ of the goldsinny were larger than the legal size limit at the time of the study $(110 \mathrm{~mm})$, compared to $93.2 \%$ for corkwing. Goldsinny mean age was 4.2 years and attained maximum age of 15 years, while the average corkwing was 1.4 years and with only one individual reaching four years. Nesting males of corkwing were larger $($ mean $=150 \mathrm{~mm})$ than females $($ mean $=137 \mathrm{~mm} ; t=7.00$, $\mathrm{df}$ $=617.93, P<0.0001)$ and sneaker males $($ mean $=127 \mathrm{~mm}, t=9.35, \mathrm{df}=106.70, P<0.0001)$, but no sexual difference was evident for goldsinny $(t=-0.54011$, $\mathrm{df}=1494.6, P=0.589)$. Pooling all sampling sites, the goldsinny sex ratio was male-biased (62.7\% males, SE=1.7), while for corkwing, the sex ratio (nesting males to females) was slightly female-biased (47.2 $\%$ nesting males, $\mathrm{SE}=2.0)$. Nesting males were more common than sneaker males $(79.3 \%$ of all males, $\mathrm{SE}=2.1$ ).

There were considerable spatial differences in catch per unit effort (CPUE), length and age for both species (Figure 2). The CPUE of legal-sized goldsinny was significantly (33-65 \%) higher within MPAs relative to harvested control areas (Table II, Figure 3(a)). For corkwing, a model with locality x protection interaction effect was supported (Table II, Figure 3(e)). Three localities had higher abundance (61-91\% observed difference in means) within MPAs, whereas the Flødevigen MPA had $16.4 \%$ lower mean CPUE relative to the control area (Figure 3b). For length and age, the model with locality x protection interaction was supported for both species (Table II). All MPA's had relatively larger and older corkwing (Figure 3(f), Figure 3(g)), with a notably higher difference between the MPA and control area in Risør (age: $39 \%$, length $16 \%$ ). On the other hand, there was no clear effect of protection on goldsinny body size and age, where the model with interaction between locality and protection was supported (Table II). Goldsinny was smaller in the MPA's with the exception of Flødevigen (Figure 3(b)). Goldsinny in Tvedestrand inner MPA was $21 \%$ older than in the control area, while the differences in means between MPA and control areas were 
234 less than $3 \%$ in the other three localities (Figure 3(c)). MPA and control areas did not differ

235 in the proportion of males for neither species (goldsinny: $\chi^{2}=1.7827, P=0.18$, corkwing $\chi^{2}=$

$2360.0076, P=0.93$ ), but there were significant differences between localities for goldsinny, with

237 more male-biased sex-ratios in Risør (Table II, Figure 3(d)).

238

239

240

241

242

243

244

245

246

247

248

249

250

251

252

253

254

255

256

257

258

259

260

261

262

263

264

265

There were significant effects of sampling gear on CPUE for both species (Table II). For goldsinny the observed mean CPUE was $32 \%$ higher in pots relative to fyke nets whereas for corkwing fyke nets had $72 \%$ higher relative mean observed CPUE. Moreover, pots caught smaller and younger goldsinny but no differences were detected for corkwing (Table II). There were close to significant differences in sex ratio between fyke nets and pots, with pots capturing more males of both species (Table II). Other species than wrasse constituted $28 \%$ of the total catch in fyke nets compared to $15 \%$ in pots (Figure 4, proportion test $\chi^{2}=149.72$, $P<0.0001$ ). Of specifically interest was by-catch of the protected eel (Anguilla anguilla (Linnaeus, 1758)), which constituted $6 \%$ of the catch in fyke nets, but less than $0.1 \%$ in pots (Figure 4, proportion test $\chi^{2}=213.41, P<0.0001$ ).

\section{Discussion}

This study applied a field-experimental approach to assess effects of harvesting wrasse to be used as cleaner fish in salmonid aquaculture on wild wrasse populations. Using four replicated MPA-control areas, we found that targeted species tended to have higher catch per unit effort (CPUE) in MPAs. For the corkwing wrasse, MPAs had consistently larger and older fish, while these life history effects for goldsinny were less clear. We also found that the two gear types can be selective on species composition and for goldsinny, size and age.

From a conservation perspective, this study adds to the growing amount of evidence of positive effects of MPAs on abundance and demographic structure of harvested fish species (Lester et al. 2009; Baskett \& Barnett 2015). In particular, both goldsinny and corkwing wrasse are sedentary, territorial reef fish with limited adult dispersal capacity, so even small protected areas like those studied here should be efficient conservation tools (Gunderson et al. 2008; Wilson et al. 2010). Both species showed positive effects of MPAs on CPUE, although in Flødevigen, CPUE was slightly lower in the MPA. The abundance, mean body size and survival of coastal cod (Gadus morhua), a potentially important wrasse predator, has increased substantially in the Flødevigen MPA after its implementation (Moland et al. 2013; Fernández-Chacón et al. 2015), so while fishing mortality may have been reduced, it is possible that this has been accompanied by an increase in natural mortality through increased 
266 predator densities (Babcock et al. 2010; Frank et al. 2011). Interestingly, the two most 267 recently established MPAs in Tvedestrand had good effect on abundance, the strongest MPA 268 effect (65\% MPA-control difference in CPUE) on goldsinny CPUE was in Tvedestrand outer 269 MPA while in Tvedestrand Inner for corkwing (91\% difference). It is possible that the fishing intensity has been higher in Tvedestrand, but alternatively it is also plausible that wrasses respond more quickly to cessation of fishing than their predators. For instance, the mentioned coastal cod is only partly protected in MPAs (it is still fished with hook and line) and has higher mobility than wrasses so a higher degree of spill-over of adults to the adjacent areas open for fishing is expected.

The MPA-effect on size and age differed between the two species; the MPAs had larger and older corkwing, but no clear pattern was evident for goldsinny. This is somewhat counterintuitive; as $92.3 \%$ of the corkwing were larger than the minimum size limit, compared with $36.6 \%$ of the goldsinny, implying that the size limit should be more selective in goldsinny. However, we sampled wrasse in August and September, which is close to the end of the wrasse fishing season, so a larger proportion of the corkwing may have been below the size limit at the start of the fishery ( 25 of May). In addition, there was larger spatial variation between the different MPAs for goldsinny age and body size, so other factors (e.g. density, predation and habitat) than fishing may have stronger effects on goldsinny life history traits than fishing. For example, the observation that the CPUE of goldsinny was generally higher than the CPUE for corkwing could imply stronger density-effects on the goldsinny. In that context, the reduced abundance of goldsinny we observed in control areas may have increased growth rates for the remaining fish. Moreover, as these two species have overlapping habitat requirements and diets (Costello 1991; Sayer et al. 1996a), a reduction in abundance of the larger corkwing wrasse could benefit the goldsinny. The considerable variation in goldsinny size and age structure over distances less than $30 \mathrm{~km}$ as found in this study implies a mismatch between the unit of management and the spatial variation in life histories. The same minimum size regulations are enforced throughout Norway, and populations with faster growth would reach the size limit at a younger age and be more prone for overexploitation. To this end, a more comprehensive spatial assessment of growth and maturation and the underlying factors causing variation should be conducted and incorporated in the management strategies. 
Corkwing nesting males were larger than females, but as we found that almost all corkwing wrasse were larger than the size limit at the time of study, the possibilities for the fisheries to be sex-selective were limited. In a study conducted during the spawning season in 2014, no sexual differences were found between mature nesting males and females in Flødevigen (Halvorsen et al. 2016), indicating that the degree of sexual size dimorphism for corkwing may be variable between years. The same study found stronger male-biased sexual size dimorphism in populations further north on the western coast compared to those on the Skagerrak coast with consequently higher potential for sex-selective harvesting.

Currently, both pots and fyke nets are used in the fishery. Many of the wrasse fishermen in Southern Norway were previously involved in a fyke-net fishery for catching eel, which was prohibited in 2010 with the eel now listed as vulnerable according to the International Union for Conservation of Nature (IUCN). A special permit has to be obtained in order to use fyke nets for fishing wrasse, and we have shown that fyke nets have a significantly higher proportion of eel and by-catch species in general. To our knowledge, fishermen release all by-catch on shallow depths, so the mortality associated with capture may be expected to be relatively low. Moreover, pots caught smaller and younger goldsinny, but this is expected as the pots used had smaller mesh size than fyke nets. No gear differences in size and age was evident for corkwing, which is most likely related to their larger size and deeper body shape relative to goldsinny.

Our study provides the first insights into the effects of harvesting of wild wrasse in Norway, but it should be noted that the wrasse landings are considerably higher in Western Norway than on the Skagerrak coastline (Espeland et al. 2010; The Norwegian Directorate of Fisheries). Salmonid aquaculture is virtually absent in Skagerrak, and harvested wrasse is transported to western and northern Norway were local wrasse population cannot sustain the demand for cleaner fish (Skiftesvik et al. 2014a). Thus, the modest, but significant differences between MPA and control areas we found here would likely have been larger if a similar study was conducted in the more intensively fished areas but which unfortunately do not have MPAs. In addition, the annual national landings have increased with $32 \%$ since this study was conducted, so the differences between fished and unexploited areas may have increased. The minimum size limit for corkwing was increased from 11 to $12 \mathrm{~cm}$ in 2015 , but still $82 \%$ of the corkwing would be harvestable using the size distribution in our data. Reduction of wrasse densities may lead to cascade effects in the coastal ecosystems where the different wrasses play a vital role as both predators on molluscs and crustaceans (Deady \& Fives 
332 1995a,b; Sayer et al. 1995) and are prey for larger species, such as gadoids, seabirds and 333 otters (Steven 1933; Rui Beja 1995; Nedreaas et al. 2008). Moreover, the wrasse diet is size 334 and sex dependent (Deady \& Fives 1995a,b; Sayer et al. 1995), thus ecological consequences 335 on prey species may be anticipated if fishing mortality is selective with regards to size and 336 sex.

\section{References}

Babcock RC, Shears NT, Alcala AC, Barrett NS, Edgar GJ, Lafferty KD, et al. 2010. Decadal trends in marine reserves reveal differential rates of change in direct and indirect effects. Proceedings of the National Academy of Sciences of the United States of America 107:18256-61.

Baskett M, Barnett L. 2015. The Ecological and Evolutionary Consequences of Marine Reserves. Annual Review of Ecology, Evolution, and Systematics 46:49-73

Besnier F, Kent M, Skern-Mauritzen R, Lien S, Malde K, Edvardsen RE, et al. 2014. Humaninduced evolution caught in action: SNP-array reveals rapid amphi-atlantic spread of pesticide resistance in the salmon ecotoparasite Lepeophtheirus salmonis. BMC genomics 15:937.

Bjordal Å. 1988. Cleaning symbiosis between wrasse (Labridae) and lice infested salmon (Salmo salar) in mariculture. International Council for the Exploration of the Sea, Mariculture Committee 188: 1-8. 
Carr MH, Reed DC. 1993. Conceptual issues relevant to marine harvest refuges: Examples from temperate reef fishes. Canadian Journal of Fisheries and Aquatic Sciences 50:20192028.

Costello, MJ. 1991. A review of the biology of wrasse (Labridae) in Northern Europe. Progress in Underwater Science 16:29-51.

Costello, MJ. 2009. The global economic cost of sea lice to the salmonid farming industry. Journal of fish diseases 32:115-8.

Darwall WRT, Costello MJ, Donnelly R, Lysaght S. 1992. Implications of life-history strategies for a new wrasse fishery. Journal of Fish Biology 41:111-123.

Deady S, Fives JM. 1995a. Diet of ballan wrasse, Labrus bergylta, and some comparisons with the diet of corkwing wrasse, Crenilabrus melops. Journal of the Marine Biological Association of the United Kingdom 75: 651-665.

Deady S, and Fives JM. 1995b. The diet of corkwing wrasse, Crenilabrus melops, in Galway Bay, Ireland, and in Dinard, France. Journal of the Marine Biological Association of the United Kingdom 75:635-649.

Dipper FA, Pullin RSV. 1979. Gonochorism and sex-inversion in British Labridae (Pisces). Journal of Zoology, London 187:97-112.

Espeland SH, Nedreaas K, Mortensen S, Skiftesvik AB, Agnalt A, Durif C, et al. 2010. Kunnskapsstatus leppefisk - Utfordringer i et økende fiskeri. Fisken og Havet. (In Norwegian)

Fernández-Chacón A, Moland E, Espeland SH, Olsen EM. 2015. Demographic effects of full vs. partial protection from harvesting: inference from an empirical before-after controlimpact study on Atlantic cod. Journal of Applied Ecology 52:1206-1215.

Frank KT, Petrie B, Fisher JAD, Leggett WC. 2011. Transient dynamics of an altered large marine ecosystem. Nature 477:86-89.

Gaines SD, White C, Carr MH, Palumbi SR. 2010. Designing marine reserve networks for both conservation and fisheries management. Proceedings of the National Academy of Sciences 107:18286-18293.

Gjøsaeter J. 2002. Fishery for goldsinny wrasse (Ctenolabrus rupestris) (Labridae) with pots along the Norwegian Skagerrak coast. Sarsia: North Atlantic Marine Science 87:83-90.

Goñi R, Hilborn R, Díaz D, Mallol S, Adlerstein S. 2010. Net contribution of spillover from a 
marine reserve to fishery catches. Marine Ecology Progress Series 400:233-243.

Gunderson DR, Parma AM, Hilborn R, Cope JM, Fluharty DL, Miller ML, et al. 2008. The Challenge of Managing Nearshore Rocky Reef Resources. Fisheries 33:172-179.

Halvorsen KT, Sørdalen TK, Durif C, Knutsen H, Olsen EM, Skiftesvik AB, et al. 2016. Male-biased sexual size dimorphism in the nest building corkwing wrasse (Symphodus melops): implications for a size regulated fishery. ICES Journal of Marine Science: Journal du Conseil advance access. doi: 10.1093/icesjms/fsw135. 9 pages-

Hilldén N-O. 1981. Territoriality and reproductive behaviour in the goldsinny, Ctenolabrus rupestris L. Behavioural Processes 6:207-221.

Lester SE, Halpern BS, Grorud-Colvert K, Lubchenco J, Ruttenberg BI, Gaines SD, et al. 2009. Biological effects within no-take marine reserves: A global synthesis. Marine Ecology Progress Series 384:33-46.

Moland E, Olsen EM, Knutsen H, Garrigou P, Espeland SH, Kleiven AR, et al. 2013. Lobster and cod benefit from small-scale northern marine protected areas: inference from an empirical before-after control-impact study. Proceedings. Biological sciences / The Royal Society 280:20122679.

Nedreaas K, Aglen A, Gjøsæter J, Jørstad K, Knutsen H, Smedstad O, et al. 2008. Management of cod in Western Norway and on the Skagerrak coast - stock status and possible management measures. FISKEN og HAVET 5

Potts GW. 1985. The Nest Structure of the Corkwing Wrasse, Crenilabrus Melops (Labridae: Teleostei). Journal of the Marine Biological Association of the United Kingdom 65:531546.

R Core Team. 2015. R: A Language and Environment for Statistical Computing. $R$ Foundation for Statistical Computing, Vienna, Austria. Computer program.

Roberts CM, Polunin NVC. 1991. Are marine reserves effective in management of reef fisheries? Reviews in Fish Biology and Fisheries 1:65-91.

Rui Beja P. 1995. Structure and Seasonal Fluctuations of Rocky Littoral Fish Assemblages in South-Western Portugal: Implications for Otter Prey Availability. Journal of the Marine Biological Association of the United Kingdom 75:833.

Sayer MDJ. 1999. Duration of refuge residence by goldsinny, Ctenolabrus rupestris. Journal of the Marine Biological Association of the UK 79:571-572. 
Sayer MDJ, Gibson RN, Atkinson RJA. 1996a. Seasonal, sexual and geographic variation in the biology of goldsinny, corkwing and rock cook on the west coast of Scotland. In: MDJ Sayer, MJ Costello, JW Treasurer, editors. Wrasse: biology and use in aquaculture. Oxford: Fishing News Books, p 13-46.

Sayer MDJ, Gibson RN, Atkinson RJA. 1996b. The biology of inshore goldsinny populations: can they sustain commercial exploitation? In: MDJ Sayer, MJ Costello, JW Treasurer, editors. Wrasse: biology and use in aquaculture. Oxford: Fishing News Books, p 91-99.

Sayer MDJ, Gibson RN Atkinson, RJA. 1995. Growth, diet and condition of goldsinny on the west coast of Scotland. Journal of Fish Biology 46:317-340.

Skiftesvik AB, Blom G, Agnalt A-L, Durif C, Browman HI, Bjelland RM, et al. 2014a. Wrasse (Labridae) as cleaner fish in salmonid aquaculture - The Hardangerfjord as a case study. Marine Biology Research 10:289-300.

Skiftesvik AB, Durif CMF, Bjelland RM, Browman HI. 2014b. Distribution and habitat preferences of five species of wrasse (family Labridae) in a Norwegian fjord. ICES Journal of Marine Science 72:890-899.

Steven GA. 1933. The Food Consumed by Shags and Cormorants around the Shores of Cornwall (England). Journal of the Marine Biological Association of the United Kingdom 19:277.

Sundt RC, Jørstad KE. 1998. Genetic population structure of goldsinny wrasse, Ctenolabrus rupestris (L.), in Norway: implications for future management of parasite cleaners in the salmon farming industry. Fisheries Management and Ecology 5:291-302.

Treasurer JW. 1996. Wrasse (Labridae) as cleaner fish of sea lice (Copepoda: Caligidae) on farmed Atlantic salmon, Salmo salar L. in west Scotland. In: MDJ Sayer, MJ Costello, JW Treasurer, editors. Wrasse: biology and use in aquaculture. Oxford: Fishing News Books, p 185-195.

Uglem I, Rosenqvist G, Wasslavik HS. 2000. Phenotypic variation between dimorphic males in corkwing wrasse. Journal of Fish Biology 57:1-14.

Varian SJ, Deady S, Fives J. 1996. The effect of intensive fishing of wild wrasse populations in Lettercallow Bay, Connemara, Ireland: implications for the future management of the fishery. In: MDJ Sayer, MJ Costello, JW Treasurer, editors. Wrasse: biology and use in aquaculture. Oxford: Fishing News Books, p 100-118. 
456 Villegas-Ríos D, Alós J, March D, Palmer M, Mucientes G, Saborido-Rey F. 2013. Home 457 range and diel behavior of the ballan wrasse, Labrus bergylta, determined by acoustic 458 telemetry. Journal of Sea Research 80:61-71.

459 Wilson, JR, Prince JD, Lenihan HS. 2010. A management strategy for sedentary nearshore 460 species that uses marine protected areas as a reference. Marine and Coastal Fisheries $461 \quad 2: 14-27$.

462

463

464

465

466

467

468

469

470

471

472

473

474

475

476

477

478

479

480

http://mc.manuscriptcentral.com/mbr Editorial Office e-mail marinebiology@imr.no 


\section{Tables}

482 Table I: Number of gear used, number $(n)$ of wrasse and goldsinny caught and aged (in 483 parenthesis) at the control and MPA sites. Time of sampling during 2013 is also given for 484 each locality. See Figure 1 for details about the localities.

\begin{tabular}{cccccc} 
Locality (date) & Treatment & Pots & Fyke nets & $\begin{array}{c}\text { n goldsinny } \\
\text { (aged) }\end{array}$ & $\begin{array}{c}\text { n corkwing } \\
\text { (aged) }\end{array}$ \\
\hline Flødevigen & MPA & 46 & 30 & $914(153)$ & $90(90)$ \\
$(30.08-03.09)$ & Control & 47 & 31 & $1249(146)$ & $112(112)$ \\
\hline Tvedestrand (inner) & MPA & 8 & 14 & $400(97)$ & $80(80)$ \\
$(24.08-29.08)$ & Control & 15 & 24 & $328(79)$ & $58(54)$ \\
\hline Tvedestrand (outer) & MPA & 6 & 6 & $195(112)$ & $117(117)$ \\
$(24.08-29.08)$ & Control & 7 & 9 & $153(98)$ & $86(86)$ \\
\hline Risør & MPA & 12 & 16 & $473(100)$ & $108(108)$ \\
$(11.09-12.09)$ & Control & 12 & 18 & $194(61)$ & $58(58)$ \\
\hline Total & MPA & 56 & 82 & $1982(462)$ & $395(395)$ \\
$(24.08-12.09)$ & Control & 65 & 98 & $1924(384)$ & $314(310)$ \\
\hline
\end{tabular}


500 Table II: Summary of the optimal generalized linear models as determined by the likelihood 501 ratio test on the effects of Protection (MPA vs control), Locality and gear on catch per unit 502 effort (CPUE), total length, age and sex ratio (proportion males, sneaker males excluded for 503 corkwing). Significant $P$-values in bold

\begin{tabular}{|c|c|c|c|c|c|c|}
\hline Response & Species & $\begin{array}{l}\text { Likelihood ratio test } \\
\text { Protection } x \text { locality }\end{array}$ & Predictors & $\chi^{2}$ & Df & $\boldsymbol{P}$ \\
\hline \multirow[t]{7}{*}{ CPUE } & Goldsinny & $\chi^{2}=1.30, P=0.72$ & Protection & 8.66 & 1 & 0.003 \\
\hline & & & Locality & 8.81 & 3 & 0.003 \\
\hline & & & Gear & 7.08 & 1 & 0.008 \\
\hline & Corkwing & $\chi^{2}=12.01, \mathbf{P}=\mathbf{0 . 0 0 7}$ & Protection & 6.18 & 1 & 0.013 \\
\hline & & & Locality & 53.40 & 3 & $<0.0001$ \\
\hline & & & Gear & 19.10 & 1 & $<0.0001$ \\
\hline & & & Protection : Locality & 12.30 & 3 & 0.006 \\
\hline \multirow[t]{8}{*}{ Length } & Goldsinny & $\chi^{2}=98.99, \mathbf{P}<\mathbf{0 . 0 0 0 1}$ & Protection & 27.58 & 1 & $<0.0001$ \\
\hline & & & Locality & 100.19 & 3 & $<0.0001$ \\
\hline & & & Gear & 448.68 & 1 & $<0.0001$ \\
\hline & & & Protection : Locality & 100.03 & 3 & $<0.0001$ \\
\hline & Corkwing & $\chi^{2}=12.37, \mathbf{P}=\mathbf{0 . 0 0 6}$ & Protection & 18.00 & 1 & $<0.0001$ \\
\hline & & & Locality & 10.74 & 3 & 0.013 \\
\hline & & & Gear & 0.03 & 1 & 0.85 \\
\hline & & & Protection : Locality & 12.32 & 3 & 0.006 \\
\hline \multirow[t]{7}{*}{ Age } & Goldsinny & $\chi^{2}=22.23, \mathbf{P}<\mathbf{0 . 0 0 0 1}$ & Protection & 6.62 & 1 & 0.010 \\
\hline & & & Locality & 56.69 & 3 & $<0.0001$ \\
\hline & & & Gear & 57.24 & 1 & $<0.0001$ \\
\hline & & & Protection : Locality & 22.23 & 3 & $<0.0001$ \\
\hline & Corkwing & $\chi^{2}=7.12, \mathrm{P}=0.07$ & Protection & 13.30 & 1 & $<0.001$ \\
\hline & & & Locality & 6.55 & 3 & 0.088 \\
\hline & & & Gear & 0.55 & 1 & 0.46 \\
\hline \multirow[t]{6}{*}{ Sex } & Goldsinny & $\chi^{2}=0.76, \mathrm{P}=0.86$ & Protection & 1.78 & 1 & 0.18 \\
\hline & & & Locality & 20.08 & 3 & 0.0001 \\
\hline & & & Gear & 3.30 & 1 & 0.069 \\
\hline & Corkwing & $\chi^{2}=4.96, \mathrm{P}=0.18$ & Protection & 0.10 & 1 & 0.75 \\
\hline & & & Locality & 5.93 & 3 & 0.12 \\
\hline & & & Gear & 3.83 & 1 & 0.050 \\
\hline
\end{tabular}

504

505

506

507

508

509

510 


\section{$511 \quad$ Figure captions}

512 Figure 1: Map showing the study area in Southern Norway (A) with the four localities along

513 the Norwegian Skagerrak coast used in this study (B). C-F shows the four MPAs (boxed areas

514 with lines) with the sampling sites (solid fill). C: Flødevigen, D: Tvedestrand Outer, E:

515 Tvedestrand Inner and F: Risør.

516 Figure 2: Boxplots showing the median (thick vertical line) and mean (solid squares) of catch 517 per unit effort (CPUE: pooled for both gear types), total length (mm) and age of goldsinny

518 and corkwing in the four sampling localities ( $\mathrm{F}=$ Flødevigen, $\mathrm{TI}=$ Tvedestrand Inner,

$519 \mathrm{TO}=$ Tvedestrand Outer and $\mathrm{R}=$ Risør). Shaded boxes are MPAs, open control sites. The upper

520 and lower edge of box represents the 25 th and 75 th percentiles, respectively. The whiskers

521 extend to the highest value maximum 1.5 times the distance between the 25 th and 75 th

522 percentiles and filled dots represents outliers.

523 Figure 3: The predicted effect of protection (MPA or control site) on catch per unit effort

524 (CPUE), body length, age and the proportion males for goldsinny and corkwing wrasse

525 captured in pots in the four localities as estimated by generalized linear models. Error bars

526 show standard error around the predicted means. For corkwing, age was modeled with a

527 binominal age distribution (0: 0-1 and 1: 2-4 years).

528 Figure 4: The relative species distribution in the two gear types used for sampling wrasse in

529 Skagerrak 2013. The data is pooled for all sampling sites. 

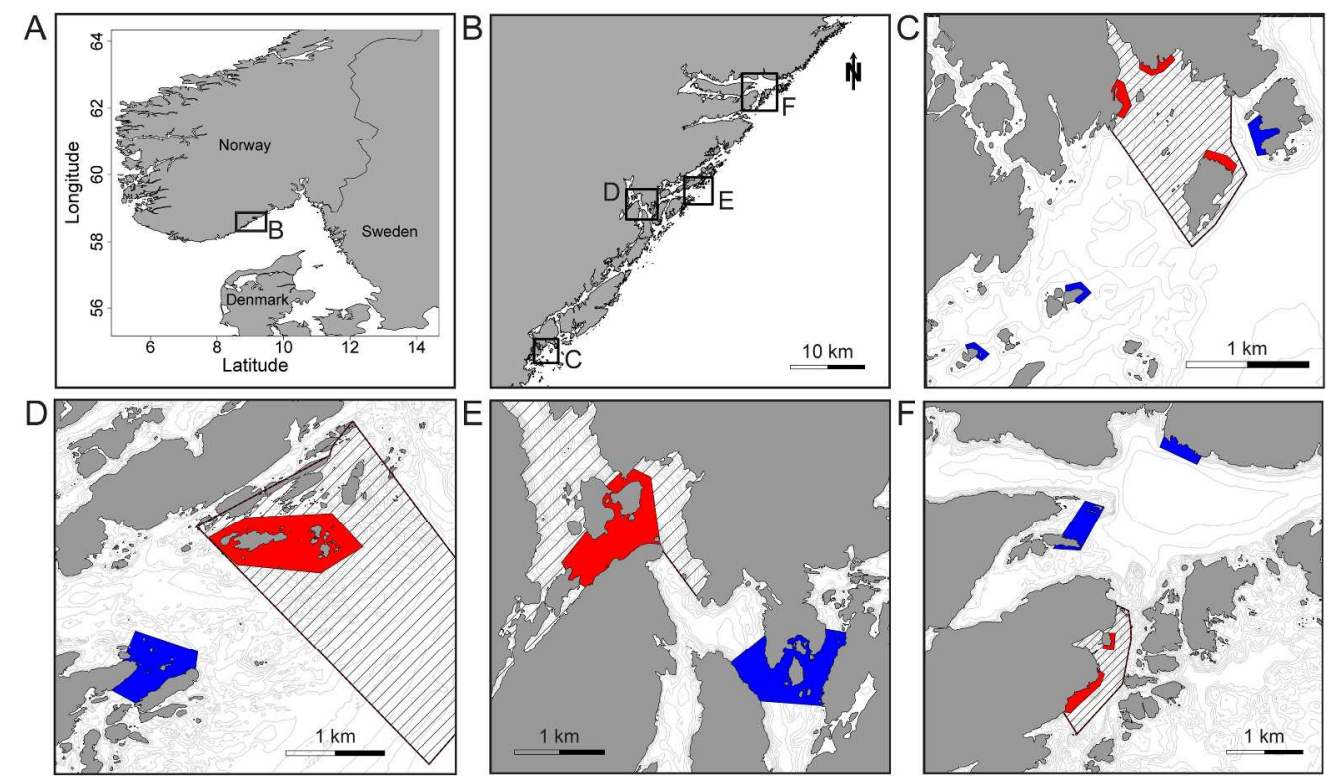

Map showing the study area in Southern Norway (A) with the four localities along the Norwegian Skagerrak coast used in this study (B). C-F shows the four MPAs (boxed areas with lines) with the sampling sites (solid fill). C: Flødevigen, D: Tvedestrand Outer, E: Tvedestrand Inner and F: Risør.

Figure 1

$254 \times 149 \mathrm{~mm}(300 \times 300 \mathrm{DPI})$ 
A
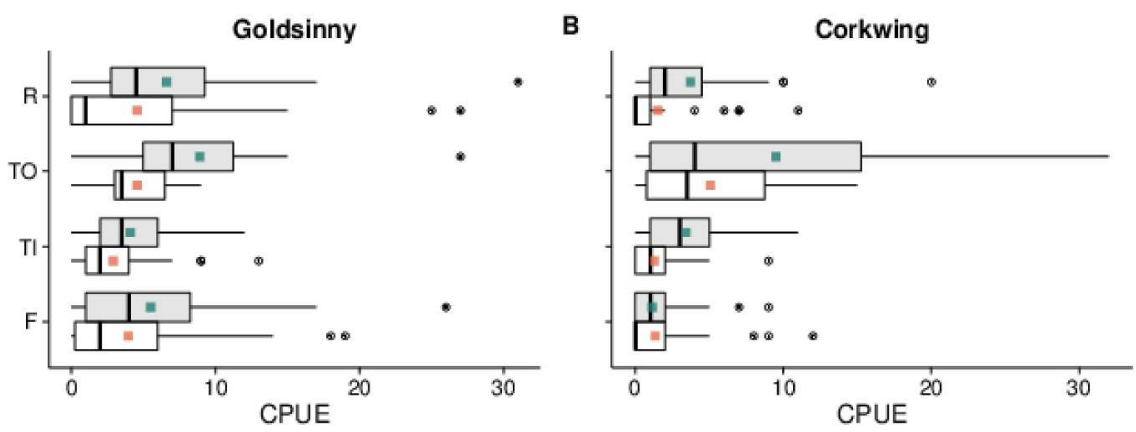

c

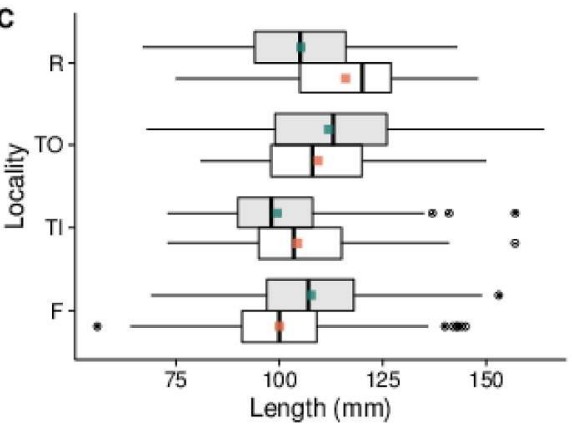

$\mathbf{F}$

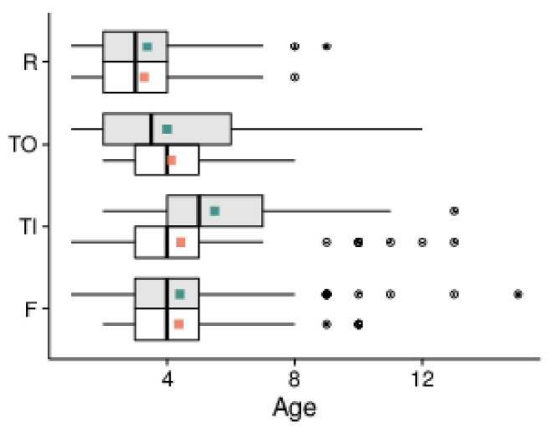

D

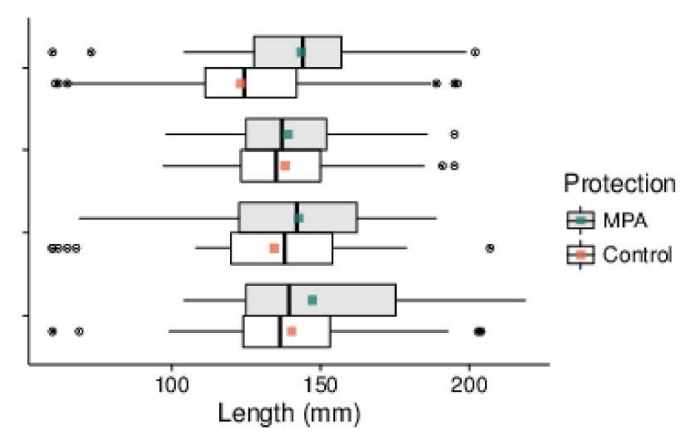

E

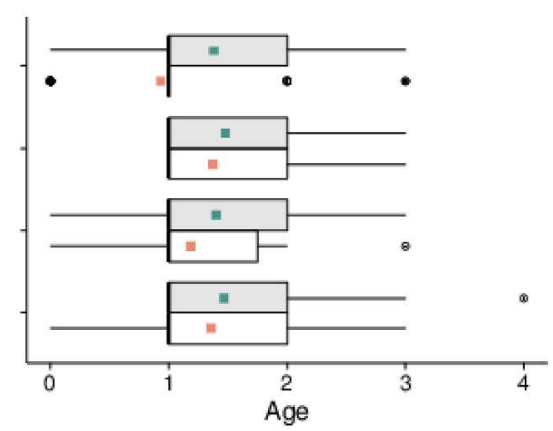

Boxplots showing the median (thick vertical line) and mean (solid squares) of catch per unit effort (CPUE: pooled for both gear types), total length $(\mathrm{mm})$ and age of goldsinny and corkwing in the four sampling localities ( $\mathrm{F}=\mathrm{Fl} \varnothing d e v i g e n, \mathrm{TI}=$ Tvedestrand Inner, $\mathrm{TO}=$ Tvedestrand Outer and $\mathrm{R}=\mathrm{Ris} \varnothing \mathrm{r}$ ). Shaded boxes are MPAs, open control sites. The upper and lower edge of box represents the 25th and 75th percentiles, respectively. The whiskers extend to the highest value maximum 1.5 times the distance between the 25th and 75th percentiles and filled dots represents outliers.

Figure 2

$254 \times 254 \mathrm{~mm}(300 \times 300$ DPI $)$ 

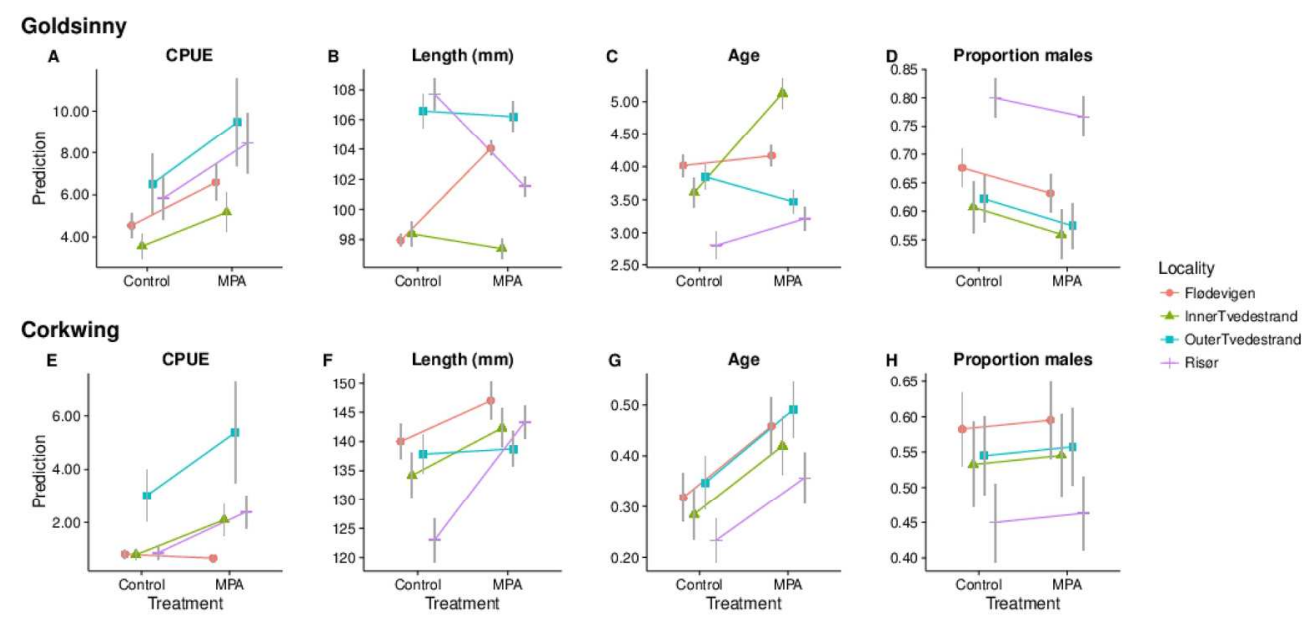

- OuterTvedestrand

+ Risor

The predicted effect of protection (MPA or control site) on catch per unit effort (CPUE), body length, age and the proportion males for goldsinny and corkwing wrasse captured in pots in the four localities as estimated by generalized linear models. Error bars show standard error around the predicted means. For corkwing, age was modeled with a binominal age distribution (0: 0-1 and 1: 2-4 years).

Figure 3

$177 \times 82 \mathrm{~mm}(300 \times 300 \mathrm{DPI})$ 


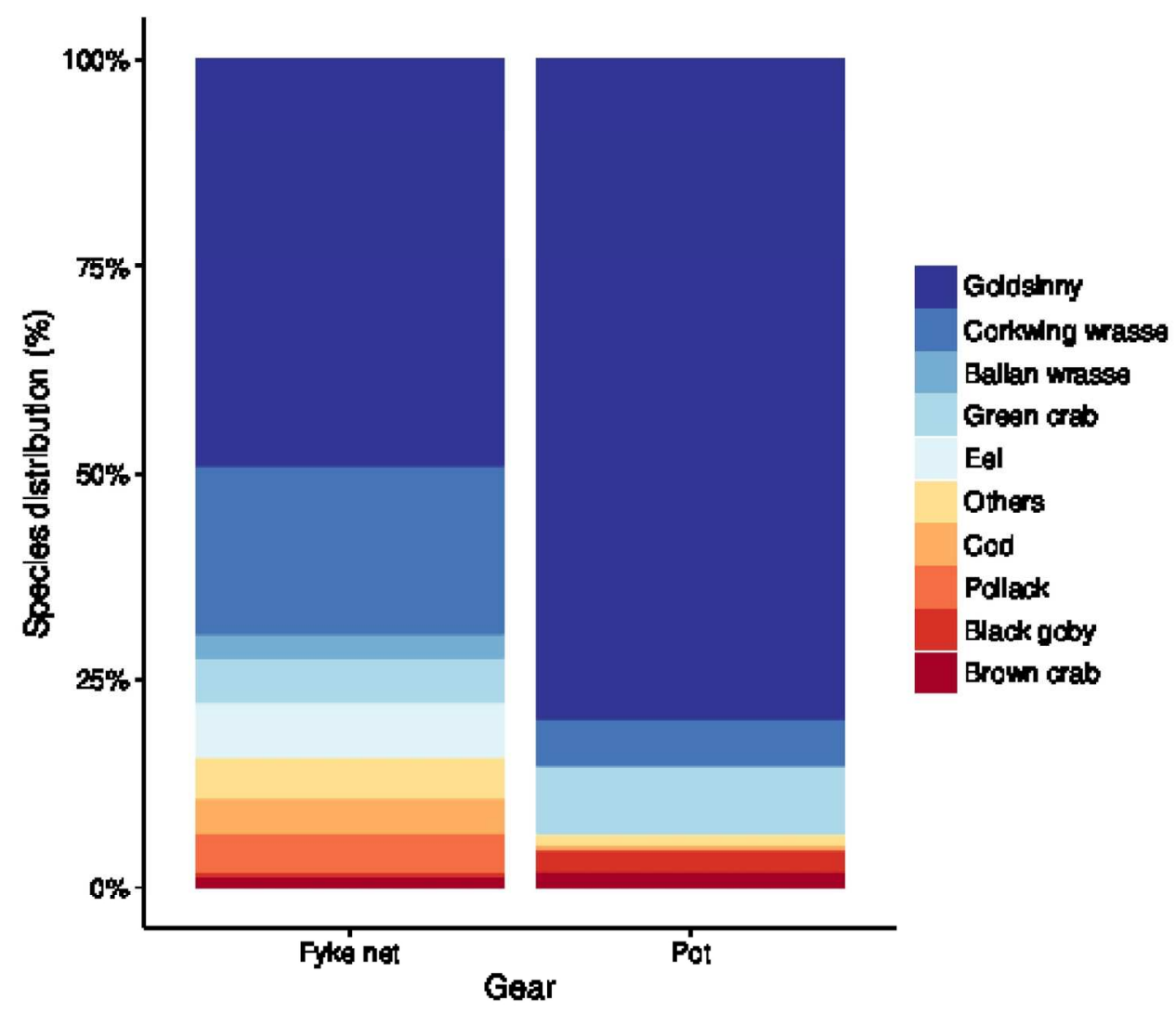

The relative species distribution in the two gear types used for sampling wrasse in Skagerrak 2013. The data is pooled for all sampling sites.

Figure 4

$160 \times 134 \mathrm{~mm}(300 \times 300 \mathrm{DPI})$ 